\title{
1 Reframing African ontologies in the era of decolonisation
}

\author{
Beschara Karam and Bruce Mutsvairo
}

The central aim of this book is to "decolonise" political communication. However, considering the complexities of the sub-field, as well as the fact that it is a theory-praxis, it is almost a near impossible claim. With regard to the complexities of political communication, we refer to how the subdiscipline (which falls within the more established field of Communication Studies) is made up of several, often dissenting, fields, such as Organisational Communication (consider, for instance, branding, institutional communication, advertising, and public relations, to mention but a few), International Communication, Government Communication, Media Studies, and Politics. With regard to the theory-praxis, it deals not only with theories such as agenda-setting, social semiotics, and framing - but also with practical skills - such as how to write a press statement, or media report - and the skills involved in being a spokesperson or speechwriter. All of which are taught within the triad of the media, politics, and citizenry that make up "political communication"; and all of which function in democratic societies. These societies privilege the west and Europe as the centre of this democracy, which in turn has capitalism as its foundation, all of which need to be unpacked and critiqued. This is a monumental undertaking for only one book, most especially because this collaborative volume is the very first scholarly work to embark on such a responsibility. Instead, we would like to present this work as a form of "problematising" the sub-field of political communication, and, as a form of "consciousness raising", about the need to decolonise this inter-disciplinary theory-praxis. Both terms are borrowed from Paulo Freire (1970), who was a ground-breaking scholar in the Latin American liberation movement. Both of his terms are understood to incorporate: self-reflexivity, theory, and action. All of which could contribute toward liberation from oppression, social change, and social justice. For Freire (1970), critical consciousness or "conscientization" (conscientização) is the noting/uncovering of social and political contradictions and acting against oppression. But not only theoretically, but also with regard to praxis, a praxis that transforms the world into something liberatory and fights oppression with regard to "problematising", it is the means by which critical engagement and "dialogue" attempt to destabilise the power relations that

DOI: $10.4324 / 9781003111962-1$ 
relate to class, gender, identity, and race (Freire 1970). This book begins the process of dialogue and self-reflexivity by interrogating the theory-practice of political communication, thereby beginning the process of creating new knowledge production about political communication in Africa. The contributing authors have done this either by using a decolonial lens, or by using decolonial research methods. We - like the seminal authors Walter Mignolo (1995, 2000), Ramón Grosfoguel (2007, 2011), Enrique Dussel (1977), Aníbal Quijano (1991, 2000), and Nelson Maldonado-Torres (2007) realise that such a decolonisation of political communication and the resultant knowledge creation need to consider the epistemic insights of authors from Africa, in the field of political communication. In other words, African authors and scholars thinking with, and from, 'subalternalized racial/ ethnic/sexual spaces and bodies' (Grosfoguel 2011:2; cf. Grosfoguel 2007). Or, put another way, it should be an example of what Archie Mafeje (2000) has called "endogeneity" - that is, African representation/scholarship that affirms African socio-economic context, positionalities, experience/s, African subjectivities and insights, and knowledge from Africa; and, in doing so, centres Africa, removing it from the margins. This edited edition is also what Grosfoguel refers to as "epistemic disobedience" in that, instead of supporting the current status quo in political communication, it serves to challenge, disrupt, destabilise, and interrogate this status quo, which, without doubt, is racialised, hierarchical, classist, capitalist, heteropatriarchal, gentrified, imperialist, and westernised. As such, it also serves to work as an agent of change by questioning post-colonialism, or, as Ndlovu-Gatsheni has argued, the 'myth of post-colonialism' (2013). In other words, it cannot be post-colonial if the "colonial matrix" still exists and continues to "entangle" us (Ndlovu-Gatsheni 2013).

Decolonisation continues to evolve. For those of us in the Global South, it is a continuous journey, perhaps a never-ending one. It is a right that should be accorded so as to preserve Indigenous intellectualism and understand the importance of intellectual freedom. It is a movement forming the basis for the preservation, defence, and promotion of home-made ideas and ways of thinking. The brutal subjugation of Indigenous peoples has had an extremely distressing impact on the colonised populations. These range from the exploitation and appropriation of their customs and cultures to endless ethnic rivalries and environmental challenges. When studying political communication, based on the available literature, we are again looking at the field that historically has largely been conceptualised from a western-centric perspective, which itself is not entirely problematic but becomes particularly objectionable when other ontologies and experiences from other regions are considered less important and unwelcome in the public discourse. For example, as argued by Bouterse and Sengupta (2018:6), it is important that alternative, non-digital sources of knowledge are equally respected because 'public knowledge online - as exemplified by Wikipedia, the fifth most-visited website in the world - is written primarily by white 
men from Europe and North America'. Those in Global South need to be content owners and content producers because being consumers of content produced in the west is no longer good enough as it leaves them relying on western ways of thinking. Africa should produce its own theories and shy away from being used as a platform to test Eurocentric ideas (Moyo 2020). The fact that some Africans may have no access to capital does not mean they have no capacity to produce their own knowledge. Political communication should be decolonised as to show the real challenges that African people, both politicians and voters, face in their quest for inclusivity. Not everyone in Africa has access to free Internet - data costs are beyond the reach of many Africans yet the political communication-related content produced in the west tends to assume that the Internet is changing political dynamics in Africa. But decolonising anything is no easy task. Decolonisation is, by nature, a complex concept. It needs to be carefully negotiated because partnership with the people who have historically benefited from coloniality is oftentimes necessary in order for it to be successful. We see the need for decolonisation but we are also cautious about unnecessary radicalisation.

As such, chapters in this book are all localised, situated, and contextbound: Africa is situated centrally, epistemologically; and most significantly, the marginalised are presented with enunciation from the subject/ subaltern or previously othered voices. It is important to note, however, that writing from and about the South or in this case Africa does not by definition make the research or knowledge creation de facto subaltern or decolonised. Neither are such scholarly contributions necessarily critical of the embedded and insidious power relations. Past scholarship has, in fact, often been merely descriptive, using African case studies, or quantitative research about politics in Africa, and therefore falls short of a decolonial critique by not interrogating the innate power relations, whether they be gendered, classist, capitalist, or racist (Olukotun \& Omotoso 2017). Because of this, the call for chapters was very specific, and we, as co-editors, would only consider chapters that are from, and about, decolonisation and political communication. That is, the book was agenda-driven: the chapters had to contribute in some way to problematising and/or decolonising political communication. By prefacing a decolonial lens or episteme, it therefore serves to challenge political communication research, which generally has its focus on empirical, quantifiable, and western knowledge (Mignolo 2011:202; cf. Thatelo 2017; Lechaba 2019). The decolonial lens, or episteme, also serves to make scholars aware of what Lewis Gordon (2000) has termed "constitutive blindness". In other words, we take it for granted that western methods of research are the only acceptable types of research. What needs to be acknowledged, therefore, is that research methods and scholarships in political communication are also historically situated or positioned through the colonisation of knowledge. In contesting this "constitutive blindness" (Gordon 2011), these chapters, or knowledge production, had to 
be articulated from beyond the othered colonial "border" line and, by doing so, take the "points of view of those whose very existence is questioned and produced as insignificant' (Maldonado-Torres 2007:262).

Nelson Maldonado-Torres, in 2006, termed the quest for decolonisation, the "decolonial turn". He, along with authors such as Walter Mignolo (2011) and Ramón Grosfoguel (2007), called for the epistemic (knowledge) decolonial turn - or as Grosfoguel stated, the call to 'epistemologically transcend, decolonize the Western canon and epistemology' (2007:211). Similarly, Archie Mafeje called for a "combative methodology" or a "combative ontology" (2000), and Walter Mignolo called for an "epistemic disobedience" (2011). In decolonising political communication, this book therefore intends to contest the "colonial power matrix" that makes up the discipline-practice (Quijano 1991, 2000) which, to reiterate, includes reified gender hierarchies, international and local racialised divisions of labour and class, aesthetic hierarchies, and epistemic hierarchies that preface, or privilege, the west over the rest. Quijano also states that his concept is an "organising principle" involving domination and exploitation and is intrinsic socio-culturally, politically, institutionally, and epistemologically (Quijano 1991, 2000). This "organising principle" is also intrinsic to political communication. Similarly, it is also, as Walter Mignolo suggests, 'a complex conceptual structure that [has] guided actions in the domain of economy (exploitation of labor and appropriation of land/natural resources), authority (government, military forces), gender/sexuality and knowledge subjectivity' (2000:19). This "colonial power matrix" ("patron de poder colonial") or "coloniality of power" (cf. Mignolo 2000) is inherent in political communication. This book intends to contest this "colonial power matrix" by providing a decolonial critique that privileges knowledge from the silenced and subalternised and transcends the western political communication canon by questioning the colonial organising "principle" that is embedded and infiltrates political communication at every level. In order to understand to what extent these hierarchical principles, organised around exploitation and domination, are "entangled", to borrow another term from Grosfoguel $(2007,2011)$ within political communication, we need to briefly "unpack" or scrutinise the discipline and practice itself.

\section{Political communication: theory-practice}

Brian McNair defines political communication as "purposeful communication about politics", which comprises of political actors (including the media, politicians, and pressure groups), political organisations (party and non-party), and the audience or citizenry (2018:4-5). All of which, in an ideal democratic society, plays out in Jürgen Habermas' public sphere (1995). As a discipline, political communication is an embryonic subject (and features as a sub-discipline) in African university curricula and appears intermittently under Communication or Communication Studies/Science and is mostly 
inter-disciplinary (cf. Olukotun \& Omotoso 2017; Mutsvairo \& Karam 2018). It is very often a misunderstood field, with many scholars and practitioners assuming that this is a study of politics proper. That is definitely not the case though. What is also apparent is that the discipline itself has cannibalised and originated from some of the more established western disciplines of organisational and corporate communication (advertising, public relations, image management, and informational management) - as well as from media studies (cultural and media studies, such as Stuart Hall's social semiotics and audience reception studies; as well as journalism), from political philosophy (such as rhetoric; cf. Edwards 2009), and from political science studies (McNair 2018). In addition to these cannibalistic components, political communication is two distinct "things": theory-practice. All of these threads or links are "entangled" and have several commonalities: they are capitalist, colonial, imperialist, and western. In a sense, this triad of politics, media, and citizenry belies its racist, classist, gentrification, hierarchical, imperialist, and heteropatriarchal western roots, as the theory-practice claims to be about democracies - and about how this triad "works" within these democracies, or "fails" in non-democracies. It sets western democracy and hegemony, along with the western preference for "scientific" research, as its benchmarks. This book therefore offers new knowledge that transcends the "Western Code" which has served "not all humanity, but only a small portion of it that benefits from the belief that is terms of epistemology there is only one game in town' (Mignolo 2011:xii).

\section{Conceptualisation of the book}

In 2018 we published an edited volume, with Palgrave Macmillan, focusing on political communication, entitled Perspectives of Political Communication in Southern Africa (Mutsvairo \& Karam 2018). The volume included authors from Africa, who wrote about African politics and the different forms of political communication. It was the first book published to write from, and about, African political communication. Despite being a cutting-edge book, and the first of its kind, it soon became apparent that the colonial matrices were still embedded in the theory-practice research; and further enquiry was needed in order to keep up with the decolonial turn.

This newly proposed book is the research that was needed to start the self-reflexive enquiry, problematisation, the disentanglement, and, most significantly, the foray into decolonising political communication, thereby encouraging a dialogue for other scholars and practitioners to do the same. It is important to note that our call is not to delegitimise western scholarship on performance and political communication. Ours is a call for inclusion. All sources of knowledge are important (Moyo \& Mutsvairo 2018). In similar vein, African knowledge should be acknowledged. We don't want to foist it on anyone, but we think it is imperative for African scholars to have an opportunity to tell their stories. However, when African scholarship is rejected, we 
should also be ready to accept that reality. We cannot fight years of endless racism and neglect with another form of bigotry. Decolonisation needs a dialogue more than anything else. In this book, we retheorise political communication and performance in the age of decolonisation, offering conceptual directions on how the field is taking shape in an era where new voices seeking inclusion and diversity of how it should be theorised continue to emerge.

\section{Chapters' overview}

The book is divided into four sections, all of which deal with media (from film to music), as well as forms of political communication, decolonisation, and performance. The very first chapter, after the introduction, Chapter 2, written by Tendai Chari, focuses on journalism and media reporting during electoral periods, and the challenge of decolonising conflict reporting in Africa (most specifically Zimbabwe). Rofhiwa Felicia Mukhudwana follows that chapter (Chapter 3) by focusing on what she terms 'conspicuous and performative blackness as decolonial political branding' with a case study on a left-wing opposition party, the Economic Freedom Fighters (Pan-Africanist). Chapter 4, written by Beschara Karam, focuses on the work of Zanele Muholi, most specifically her film, Difficult Love (Goldsmid \& Muholi 2010). That chapter is followed by Pier Paolo Frassinelli's research (Chapter 5), which argues for documentary film as political communication in post-apartheid South Africa. He focuses on several films, which he argues, seek to subvert hegemonic or state sanctioned narratives in post-apartheid. Chapter 6, written by George Nyabuga, focuses on the use of photography in political activism and resistance as forms of "remembering and memorising". Chapter 7, written by Sayan Dey, argues that the photography of the Siddis (believed to be the descendants of the Zulu people from South Africa), a community in Karnataka, is a form of visual colonialism. In this instance, the camera lens works as a colonial tool to further legitimise the marginalisation and othering of the Siddis. In Chapter 8, Sally Osei-Appiah conducts research sitting at the intersection of gender, political communication, and decolonisation in Ghana. Chapter 9 begins the section on music as disruption, political communication, and decolonisation. Here, Salim Washington writes about the "the revolutionary implications of the jazz imaginary". Chapter 10 has contributor, Africanus L. Diedong, exploring how community radio stations actually enable citizen's participation in broadcasting in Ghana using the empowerment theory. While Chapter 11, written by Wilson Ugangu, researches Kenya's "Ghetto Radio" as a "politicised space", Chapter 12 is jointly authored by Trust Matsilele and Bruce Mutsvairo, and examines social media as a sphere of political disruption in Zimbabwe's cyber sphere using \#ThisFlag digital campaign as a point of departure. Chapter 13, written by Ylva Rodny-Gumede, deals with the transformation, fragmentation, and decolonisation of the role of the media. Chapter 14, the last chapter of the book, is written by Lorenzo Dalvit, 
where he suggests that while digital media can be arguably seen as a way to revolutionise public debate, by giving "voice to the voiceless", his chapter problematises which/whose voices.

\section{Conclusion}

In concluding, the aim of this book is to function as a change agent for the theory-practice of political communication in Africa, by problematising the power matrices that are embedded within, and its over-reliance on western epistemes, that dis-members its citizenry; de-contextualises; and depositions; by privileging "numbers"/quantification; objectivity and politics as a "science". It aims to delink or disentangle the western theory-practice that dominates both the field and the discipline of political communication in Africa, and other parts of the world. We believe that these chapters which preface dialogue, consciousness raising, social justice, social and political change, cognisance of context, social agency, self-reflexivity, and the inclusion of the sub-alterns - will make an indispensable contribution to the field of political communication and the (ongoing) call for decolonisation.

\section{References}

Bouterse, S, \& Sengupta, A. 2018. Decolonising the Internet: Whose knowledge. Retrieved: https://whoseknowledge.org/wp-content/uploads/2018/11/DTI-2018Summary-Report.pdf

Dussel, E. 1977. Philosophy of Liberation. Translated by Martínez, A. and Morkovsky, C. New York: Orbis Books.

Edwards, JL. 2009. Gender and political communication in America: Rhetoric, representation, and display. Plymouth: Lexington Books.

Freire, P. 1970. The pedagogy of the oppressed. New York: Continuum.

Goldsmid, P. \& Muholi, Z. (dir). 2010. Difficult love. [Film]. Johannesburg: South African Broadcasting Corporation. The entire film can be viewed for free at: https://www.imdb.com/video/vi3128728089

Gordon, L. (2000) Existentia Africana: Understanding Africana Existential Thought. New York: Routledge.

Grosfoguel, R. 2007. The epistemic decolonial turn. Cultural Studies, 21(2-3): 211-223.

Grosfoguel, R. 2011. Decolonizing post-colonial studies and paradigms of politicaleconomy: Transmodernity, decolonial thinking and global coloniality. Transmodernity: Journal of Peripheral Cultural Produduction of the Luso-Hispanic World, 1(1): $1-38$.

Habermas J. 1995. The Theory of Communicative Action, Reason and The Rationonalization of Society, Tr.T., Mc Carthy, Cambridge: Polity Press.

Lechaba, L. 2019. Textual analysis of selected articles from "The Thinker" magazine (2010-2016). MA study. http://uir.unisa.ac.za/bitstream/handle/10500/26314/ dissertation_lechaba_lt.pdf?sequence $=1 \&$ isAllowed=y

Mafeje, A. 2000. Africanity: a combative ontology. CODESRIA Bulletin, (1):66-71

Maldonado-Torres. 2007. On the coloniality of being. CulturalStudies 21(2-3): $240-270$. 


\section{Beschara Karam and Bruce Mutsvairo}

McNair, B. 2018. An introduction to political communication. London: Palgrave.

Mignolo, W. 1995. The Darker Side of the Renaissance: Literacy, Territoriality and Colonization. Ann Arbor: Michigan University Press.

Mignolo, W. 2000. Local Histories/Global Designs: Coloniality, Subaltern Knowledges, and Border Thinking. Ceeton: Princeton University Press.

Mignolo, W. 2011. The darker side of western modernity. Global futures, decolonial options. Durham \& London: Duke University Press.

Moyo, L. 2020. The decolonial turn in media studies in Africa and the Global South. London and New York: Palgrave-McMillan.

Moyo, L, \& Mutsvairo, B. 2018. Can the subaltern think? The decolonial turn in media research in Africa. In Bruce Mutsvairo (ed), Palgrave handbook for media and communication research in a Africa. London: Palgrave Macmillan, pp. 26-40.

Mutsvairo, B, \& Karam, B. eds. 2018. Perspectives of political communication in Africa. London: Palgrave.

Quijano, A. 1991. Coloniality and modernity /rationality. Indigenous Peru, 13(29): 11-20.

Quijano, A. 2000. Coloniality of power and social classification. Journal of World-Systems Research, VI(2): 342-386.

Olukotun, A, \& Omotoso, SA. eds. 2017. Political communication in Africa. Switzerland: Springer.

Thatelo, MT. 2017. A social semiotic analysis of the verbal, non-verbal and visual rhetoric of the 2009 and 2014 African National Congress (A.N.C.) political television advertisements: a comparative qualitative content analysis study. MA study. http:// uir.unisa.ac.za/handle/10500/25218 